\title{
POLLINATION EFFECTIVENESS OF APIS CERANA FABRICUS AND APIS MELLIFERA LINNAEUS (HYMENOPTERA: APIDAE) IN JATROPHA CURCAS L. (EUPHORBIACEAE)
}

\author{
TRI ATMOWIDI*, PUJI RIYANTI, ANDENG SUTRISNA \\ Department of Biology, Faculty of Mathematics and Natural Sciences, Bogor Agricultural University, \\ Darmaga Campus, Bogor 16680, Indonesia
}

\begin{abstract}
Pollinators are well known to provide key ecosystem. Animal pollinators are thought to contribute between 15 and $30 \%$ of global food production and bees are recognized to be the most important taxon. The pollination effectiveness of two species of bees, Apis cerana and A. mellifera (Hymenoptera: Apidae) in Jatropha curcas (Euphorbiaceae) was studied. Three cages, made of insect screen were set up. Each cage contains three individual plants. One colony of $A$. mellifera and $A$. cerana were placed in the first and second cage, while the third cage was used for control plants. Bee colonies were placed during one month in the first and second cages. Fruit set of plants pollinated by $A$. mellifera, A. cerana, control plants, and open plants were counted and compared. Pollination by honeybees increased the number of fruits per plant and fruits per raceme of $J$. curcas. Based on measuring of fruit produced by plants, pollination effectiveness of $A$. mellifera was higher than A. carana.
\end{abstract}

Key words: Pollination, effectiveness, Apis cerana, A. mellifera, seed set, Jatropha curcas.

\section{INTRODUCTION}

The honeybees are the principal species used for crop pollination worldwide (Free 1993). The true honeybees (Tribe Apini, genus Apis) consist of nine species i.e. A. mellifera Linnaeus, $A$. cerana Fabricus, $A$. dorsata Fabricus, $A$. laboriosa Smith, $A$. florea Fabricus, $A$. andreniformis Smith, A. koschevnikovi Buttel-Reepen, A. nigrocincta, dan $A$. nuluensis. Genus Apis primarily tropical was restricted to the Old World until $A$. mellifera was introduced worldwide. Both species, $A$. cerana and A. mellifera consist of medium -sized (10-11 mm) species with multiple combs in cavities, dances on vertical surfaces of combs in the dark (Michener 2000). The combs are built under the ceiling of the cavity and attached to the cavity's walls. The arrangement and distribution on the combs are similar in all races of each species (Koeniger 1995). Colonies of A. cerana are relatively small (6000-7000 workers), but $A$. mellifera colonies consist of 100, 000 or more individuals (Winston 1987). 
Comparative foraging behaviour of $A$. cerana and $A$. mellifera on apple orchard had been reported by Verma (1995). Worker bees of $A$. cerana started their foraging activity significantly earlier in the morning $(06.03 \mathrm{~h})$ than $A$. mellifera $(06.27 \mathrm{~h})$, but duration of foraging trip of $A$. mellifera (17.92 minutes) was significantly longer than that of $A$. cerana (11.85 minutes). The peak of foraging activities of $A$. cerana was between $09.00 \mathrm{~h}$ and $13.00 \mathrm{~h}$ with a temperature range of $15.5-21^{\circ} \mathrm{C}$, and that of $A$. mellifera was between $11.00 \mathrm{~h}-13.20 \mathrm{~h}$ with a temperature range from 21 to $25^{\circ} \mathrm{C}$. Worker bees of A. mellifera carried significantly heavier pollen loads than $A$. cerana throughout the day. A. cerana contacted the stigma on average 3.09 stigmas per visit and spent 5.90 seconds on each flower, whereas these values for $A$. mellifera were 3.33 stigmas per visit and 6.63 seconds on each flower, respectively (Verma 1995).

Selection for effective pollen transfer and receipt has been considered to be the principal force in the evolution of the angiosperm flower. Most flowers, however, allow access to a variety of visitors (Faegri \& van der Pijl 1979). Differences among visitors in morphology, physiology, and foraging behavior may result in differences in their effectiveness as pollinators (Young 1988). Wallace et al. (2002) also reported that the natural pollinators were extremely efficient in producing fertilization and fruit set of Jeffersonian virgata. In male-sterile oilseed rape (Brassica napus), Steffan-Dewenter (2003) reported that insect pollination can positively affect several yield components. However, these effects are dependent on cultivar and growing conditions. Total yields are often not increased due to the considerable compensatory capacity of oilseed rape (Westcott \& Nelson 2001).

Jatropha curcas (Euphorbiaceae) is a perennial, deciduous shrub or treelet. The plant produces flowers in racemose inflorescences, with dichasial cyme pattern. The flowers are unisexual, and male and female flowers are produced in the same inflorescence. Normally, the inflorescences produce a central female flower surrounded by a group of male flowers. In some cases the female flowers are substituted by male flowers. Numerically, 1-5 female flowers and 25-93 male flowers are produced per inflorescence. The average male to female flower ratio is $29: 1$. Each inflorescence, once it begins flowering, flowers daily, and the flowering lasts for 11 days. The flowering pattern showed that the male flowers are produced earlier (compared to the female flowers) and will produce flowers daily until the male buds are exhausted. The female flowers bloom between the second and the sixth day. The floral base contains nectar in trace amount, which is $0.3 \mathrm{ml}$ per flower. The flowers open daily during $0530-0630 \mathrm{~h}$. The unpollinated flowers fall off on the fourth day, while the pollinated ones remain in place. The sepals and petals gradually enlarge and protect the growing fruit until the latter reaches its full size (Raju \& Ezradanam 2002).

Here, we studied the pollination effectiveness of two species of honeybees, Apis cerana and $A$. mellifera in $J$. curcas. The effectiveness of the pollinators was measured by the number of seeds set, and seeds weight.

\section{MATERIALS AND METHODS}

\section{Study site}

The study was conducted in Jatropha plantation located at Indramayu district, West Java from May to September 2007. 


\section{Measuring of the pollination effectiveness of honeybees}

The plants selected for measuring pollination effectiveness were about three years old. We set up three cages made by of insect screen. The size of each cage was $9 \times 3 \times 2.5 \mathrm{~m}^{3}$ and each cage contains three plants of J.curcas. One colony of A. cerana and A. mellifera were placed in the first and second cages for approximately 1 month (June 22 to July 25 , 2007) to pollinate the flowers. Third cage was used as a control (no bee application). At this time, bees were fed with honey that placed in a cup. Each inflorescence observed was tagged by color ribbon. After the end of the fruiting period, the number of fruits per plant, fruits per raceme, seeds per fruit, and seed weight were counted.

\section{Observation of flower visitors}

Species composition of floral visitors was observed visually at Jatropha plantation using scan sampling method (Martin \& Bateson 1993) for a few days. After observation, insect visitors were caught by sweep netting for species identification in the laboratory.

\section{Data analysis}

Fruits set of J. curcas pollinated by $A$. cerana and A. mellifera were compared with control plants and open plants (plants pollinated by natural pollinators). Differences in fruit numbers of $J$. curcas pollinated by bees, control plants, and open plants were analysed by analysis of variance (Anova) and Scheffe test at the $95 \%$ level by using Systat 10 for Windows.

\section{RESULTS AND DISCUSSION}

\section{Pollination effectiveness of honeybees in J. curcas}

Pollination effectiveness of two species of honeybees in J. curcas varied. Pollination effectiveness was shown by the number of fruits produced by plants. Result showed that the mean number of fruits produced per plant as a result of pollination by $A$. cerana (17 fruits), A. mellifera (19 fruits), and open plants (16 fruits) were higher than that of control plants (5 fruits) (Table 1). Although, based on statistical tests, they were not significantly different.

Table 1. Reproductive success of J. curcas pollinated by A. cerana, A. mellifera, open plants, and control plants

\begin{tabular}{ccccc}
\hline \multirow{2}{*}{ Plant reproductive success } & \multicolumn{3}{c}{ Numbers $( \pm$ st.dev $)$} & \multirow{2}{*}{ Control plants } \\
\cline { 2 - 4 } & A. cerana & A. mellifera & Open plants & \\
\hline Number of fruits per plant & $17^{\mathrm{a}}( \pm 7.94)$ & $19^{\mathrm{a}}( \pm 11.93)$ & $16^{\mathrm{a}}( \pm 12.15)$ & $5^{\mathrm{a}}( \pm 5.13)$ \\
Number of fruits per raceme & $2.04^{\mathrm{a}}( \pm 1.65)$ & $3.05^{\mathrm{a}}( \pm 1.75)$ & $2.45^{\mathrm{a}}( \pm 1.47)$ & $2.29^{\mathrm{a}}( \pm 1.25)$ \\
Number of seeds per fruit & $2.76^{\mathrm{a}}( \pm 0.51)$ & $2.61^{\mathrm{a}}( \pm 0.50)$ & $2.47^{\mathrm{a}}( \pm 0.63)$ & $2.63^{\mathrm{a}}( \pm 0.52)$ \\
Seed weight $(\mathrm{g})$ & $0.47^{\text {ac }}( \pm 0.17)$ & $0.39^{\mathrm{b}}( \pm 0.14)$ & $0.51^{\mathrm{a}}( \pm 0.16)$ & $0.41^{\mathrm{cb}}( \pm 0.11)$ \\
\hline
\end{tabular}

Note: Different lower case letters in the same row indicate different values based on analysis of variance (Anova) and Scheffe test at $95 \%$ level $(\mathrm{p}<0.05)$. 
The number of fruits per raceme of plants pollinated by $A$. cerana was lowest (2.04 fruits) compared to plants pollinated by $A$. mellifera (3.05 fruits), open plants ( 2.45 fruits), and control plants (2.29 fruits). Pollination by bees increased the number of fruits per plant and fruits per raceme of $J$. curcas. Mean number of seeds per fruit of plants pollinated by $A$. cerana, $A$. mellifera, open plants, and control plants were 2.76, 2.61, 2.47 , and 2.63 seeds, respectively. The number of seeds per fruit ranged from 1 to 3 seeds (Table 1).

Results showed that $A$. mellifera was the superior pollinator compared to $A$. cerana. In addition, the number of fruits per plant and fruits per raceme of plants pollinated by A. mellifera were higher than that pollinated by A. cerana. Verma (1995) stated that some characteristics of $A$. mellifera were better than $A$. cerana, i.e. duration of foraging trip was significantly longer and worker bees carried significantly heavier pollen loads throughout the day.

The increased yields of $J$. curcas pollinated by bees was probably caused by cross pollination. As stated by Westcott \& Nelson (2001), insect pollination leads to earlier cessation of flowering and more synchronous pod and seed ripening, thereby possibly increasing the weight of seed harvest. The natural pollinators were extremely efficient in producing fertilization and fruit set of $P$. virgata (Wallace et al. 2002). In male-sterile oilseed rape (B. napus), Steffan-Dewenter (2003) reported insect pollination could positively affect several yield components. However, these effects are dependent on cultivar and growing conditions and total yields are often not increased due to the considerable compensatory capacity of oilseed rape (Westcott \& Nelson, 2001). Similarly, Atmowidi et al. (2007) reported that mustard (Brassica rapa) pollinated by insects (mostly by bees) increased the number of pods, seeds per pod, and seeds per plant.

Lower fruit set of $J$. curcas plants caged with insect screen could be caused by other factors, such as the number of plants observed, size of plants, and screen effect. The number of plants observed (three plants for each application) very limited. Size of plants observed was quite uniform, but individual variation in size occurred. The screen may be affected to plant photosynthetic rate, but most probably this effect is small, because the screen transmitted the light intensity easily.

The natural fruit set rate indicates that $J$. curcas does not suffer seriously if there are no other pollination agents. Flowers of the species are unisexual, and male and female flowers are produced in the same inflorescence. The production of female flowers in small number, surrounded by a large number of male flowers seems to be a strategy to ensure pollination to the maximum extent. The stigma receptivity lasting three days also additionally provides opportunities for pollination, if not pollinated on the first and second day. However, the plant with predominant xenogamy requires mostly xenogamous pollen for more fruit set, after selective elimination of growing fruit. Therefore, pollen transfer between conspecific has a great influence on the net percentage of natural fruit set (Raju \& Ezradanam 2002).

\section{Diversity of flower visitors}

Based on field observations, the flower-visitors of $J$. curcas belong to bees and ants (Hymenoptera), butterflies and moths (Lepidoptera), beetles (Coleoptera), thrips (Thysanoptera), and flies (Diptera). Bee species belonging to A. cerana, Ceratina sp, Trigona sp., and Hylaeus sp. were found visiting the flowers. At least, three species of 
butterflies (Nyctemera sp., Eurema hecabe, and Neptis hylas) also visited the flowers. Snout beetle and some species of Diptera (Syrphus balteatus, Sarcophaga sp., and Musca domestica), and thrips were also found visiting the flowers.

In general, insect pollinators visit the flowers in the morning. On Brassica rapa (Brassicaceae), the peak abundance of insect pollinators occurred between 08.30-09.30 h (Atmowidi et al. 2007). Similar visitation was shown by two species of pollinators (Trigona carbonari: Apidae and Leiopcoctus speculiferus: Colletidae) visited Persoonia virgata (Proteaceae) occurred before $12.00 \mathrm{~h}$ (Wallace et al. 2002). Foraging time of insect pollinators related to plant resources, especially pollen and nectar. The increase of plant resources such as during mass flowering showed an increase in available resources so that the foragers could collect more rewards per unit time. If resources are limited, the foragers require longer searches and travel time (Wesphal et al. 2006). Generally, both pollen and nectar content of most plants are higher in the morning.

\section{CONCLUSIONS}

Pollination by honeybees, $A$. cerana and $A$. mellifera increased the number of fruits per plant and fruits per raceme of $J$. curcas. In J. curcas, pollination effectiveness of $A$. mellifera was higher than that A. cerana. Naturally, flowers of J. curcas are visited by bees and ants (Hymenoptera), butterflies and moth (Lepidoptera), beetles (Coleoptera), thrips (Thysanoptera), and flies (Diptera).

\section{ACKNOWLEDGMENTS}

This project was funded by BIOTROP DIPA 2007. We greatly acknowledge Dr. Sih Kahono, Dr. Rosichon Ubaidillah, Dr. Yayuk Rahayuningsih, Woro Nurjito,M.Sc. and Pudji Aswari, M.Sc. of Zoological Museum, Indonesian Institute of Science, Cibinong for their help in identification of insect pollinators. We are also grateful to Dian Sari and Sunaryo for the assistance in collecting the data. Finally, the authors are grateful to the two anonymous referees for their comments of this manuscript.

\section{REFERENCES}

Atmowidi T, Buchori D, Manuwoto S, Suryobroto B, Hidayat P. 2007. Diversity of insect pollinators and seed set of mustard (Brassica rapa: Brassicaceae). Hayati 14:155-161.

Faegry K, van Der Pijl L. 1971. The Principles of Pollination Ecology. Ed ke-2. Braunschweig: Pergamon Press.

Free JB. 1993. Insect Pollination of Crops. San Diego: Academic Press.

Koeniger N. 1995. Biology of the eastern honeybee Apis cerana (Fabricus 1773). In: Kevan PG, editor. The Asiatic Hive Bee: Apiculture, Biology, and Role in Sustainable Development in Tropical and Subtropical Asia. Ontario: Enviroquest Ltd. pages 29-39. 
Martin P, Bateson P. 1993. Measuring Behaviour: An Introductory Guide. Ed ke2. Cambrige: Cambrige Univ. Press.

Michener DM. 2000. The Bees of the World. Baltimore: Johns Hopkins Univ. Press.

Raju AJS, Ezradanam V. 2002. Pollination ecology and fruiting behaviour in a monoecious species, Jatropha curcas L. (Euphorbiaceae). Current Science 83:1395-1398.

Steffan-Dewenter I. 2003. Seed set of male-sterile and male-fertile oilseed rape (Brassica napus) in relation to pollinator density. Apidologie 34:227-235.

Verma LR. 1995. Apis cerana: biometric, genetic, and behavioural aspects. In: Kevan PG, editor. The Asiatic Hive Bee: Apiculture, Biology, and Role in Sustainable Development in Tropical and Subtropical Asia. Ontario: Enviroquest Ltd. Hlm 41-53.

Wallace HM, Maynard GV, Trueman SJ. 2002. Insect flower visitors, foraging behaviour and their effectiveness as pollinators of Persoonia virgata R. Br. (Proteaceae). Australian Journal of Entomology 41: 5559.

Wesphal C, Steffan-Dewenter I, Tscharntke T. 2006. Foraging trip duration of bumblebees in relation to landscape-wide resource availability. Ecological Entomology 31:389-394.

Westcott L, Nelson D. 2001. Canola pollination: an update, Bee World 82:115-129.

Winston ML. 1987. The Biology of the Honey Bee. Cambridge: Harvard Univ. Press.

Young HJ. 1988. Differential importance of beetle species pollinating Dieffenbachia longispatha (Araceae). Ecology 69:832-844. 